Article

\title{
Dependence of Weed Composition on Cultivated Plant Species and Varieties in Energy-Tree and -Grass Plantations
}

\author{
Alexander Fehér ${ }^{1}\left[\right.$, Eduard Pintér ${ }^{2}\left[\right.$, Piotr Prus ${ }^{3}\left(\mathbb{C}\right.$ and Lýdia Končeková ${ }^{1, *(1)}$ \\ 1 Department of Environmental Management, Faculty of European Studies and Regional Development, \\ Slovak University of Agriculture in Nitra, Mariánska 10, SK-949 76 Nitra, Slovakia; alexander.feher@uniag.sk \\ 2 Department of Fruit Growing, Viticulture and Enology, Slovak University of Agriculture in Nitra, \\ Mariánska 10, SK-949 76 Nitra, Slovakia; eduard.pinter@uniag.sk \\ 3 Laboratory of Economics and Counseling in Agribusiness, Department of Agronomy, Faculty of Agriculture \\ and Biotechnology, UTP University of Science and Technology in Bydgoszcz, Fordońska 430 str., \\ 85-790 Bydgoszcz, Poland; piotr.prus@utp.edu.pl \\ * Correspondence: lydia.koncekova@uniag.sk; Tel.: +421-37-641-5618
}

Received: 29 July 2020; Accepted: 21 August 2020; Published: 24 August 2020

\begin{abstract}
Energy plantations create new habitats in agricultural landscapes with species compositions different from those in forests or farmlands. The purpose of our nine-year research project (2010-2018) was to evaluate the dependence of weed-species richness and their selected ecological aspects on stands of energy-plant species, and varieties in energy-tree and -grass plantations in conditions of Central Europe, on the basis of a case study. The permanent research plots were established in plantations containing two varieties of willow (Tordis and Inger), one poplar variety (Pegaso), and one clone of Miscanthus $\times$ giganteus. This evaluation included the species composition of understory flora, habitat preferences of different species, life cycle, life forms, ecological demands, and the harmfulness of these weed-species. The ground flora of energy plantations is predominantly composed of synanthropic plants of a weedy character with differences in species composition among different energy-tree and -grass species and varieties. The total number of vascular plant species was 98. The highest number of species (58) was recorded in the Tordis and Inger willow varieties, and the lowest was observed in the Pegaso poplar variety (45). Perennial species prevailed by their share, 10 of which were found in all four research plots. Therophytes and hemicryptophytes prevailed. Most species have high light requirements and are typical for mild-to-warm suboceanic areas, demanding freshly moist alkalic soils that are medium-to-rich in mineral nitrogen. Fifty percent of all observed species are considered weeds in Slovakia. The "very dangerous" category represented $46.94 \%$ of weeds, the "less dangerous" category $51.02 \%$, and the "nondangerous" category represented $2.04 \%$ out of 49 species. The biggest share of "very dangerous weeds" was found in the poplar stand $(38.78 \%)$, less in willow (32.65\% and $28.57 \%)$, and the least in miscanthus stands (26.53\%). The weeds of the Tordis variety were relatively poorly influenced by specific environmental conditions, and the weeds of the Inger variety were mainly defined by the soil reaction. Weeds in the undergrowth of both Miscanthus $\times$ giganteus and poplar trees (Pegaso) had the greatest affinity to mineral nitrogen content and temperature requirements.
\end{abstract}

Keywords: biodiversity; miscanthus; poplar; short-rotation coppice; weed; willow

\section{Introduction}

Agricultural-land use is one of the key pressure points on biodiversity [1]. The impact of agriculture on biodiversity is attributed to, first of all, the conversion of natural ecosystems to crop fields, but also 
the fragmentation of natural habitats and effects on neighboring ecosystems, such as excess nutrients and pollutants, or the diversion of water to crops. On the other hand, agriculture benefits many wild species by providing novel ecotones and a diverse mosaic of habitats, as well as plentiful foraging resources and a suitable disturbance regime [2].

The production of biomass destined for the energy-conversion processes should be derived from surplus agricultural lands and from lands requiring soil protection against erosion. The amount of this land can be very different in different countries or regions. Short-rotation coppice (SRC) is a second-generation biomass-energy crop type established on agricultural land [3], and it refers to an intermediate habitat between forest and farmland [4,5]. Despite the benefits of energy crops (e.g., biomass production for fuel, phytoremediation, and bioengineering [6]), there is a lack of knowledge about the biodiversity of energy plantations [5,7-14]. Volk et al. [15] indicated that woody energy crops enhance biodiversity and provide diverse habitats (the combination of different varieties and growth stages creates a structurally diverse habitat for a range of wildlife). On the other hand, weed competition causes yield losses of energy plants [8]. In energy plantations, the best habitats for weed flora are created by willows, poplars, black locusts, and perennial grass [4]. Biodiversity studies on SRC showed different and sometimes contradictory results caused by different time horizons, scales of observation, and definitions of biodiversity $[5,16]$.

From an agricultural point of view, spontaneous vascular plant species in energy plantations can be classified as weeds (defined in Section 2.3). A plant with generalized weed characteristics is called an ideal weed. This type of weed has traits such as the ability to germinate in a wide range of environmental conditions, long-lived seeds with discontinuous germination, rapid growth from the vegetative to the flowering stage and propagules, and adaptation to short- and long-distance dispersal [17]. Of course, every weed species usually only has a select set of these features. Energy plantations without weed control can become a source of propagules of weeds harmful to farmland [4] (sensu lato invasion). Certain parts of weeds in energy-plant stands behave invasively. According to Crawley [18], there is no sense in searching for the traits of invasive and noninvasive species, because the ability to increase when rare is exhibited by all species in their native habitats, i.e., all plant species are invasive under certain environmental conditions. Recently, the word "invasive" has been used only for aliens [19].

The weed flora is a useful indicator for the rapid visual indication of environmental conditions in farmlands, such as microclimate, soil structure, nutrient content, moisture, and cultivation methods. On the other hand, high ecological plasticity sometimes overshadows some specific requirements [20].

Considering specific ecological and cultivation conditions of energy-plant stands, we assumed different weed-species compositions in different cultivated species or varieties of energy plantations. According to our hypothesis, energy plantations are invaded by weeds from the adjacent farmland in relation to ecological conditions (light, temperature, etc.) provided by energy plant species or varieties, and these energy-plant stands can also become a new and stable source of weeds for the neighboring agricultural land. Our paper is a case study on the species richness of weed communities and similarity of weeds among different energy-plant species and varieties, including habitat preferences, life cycles, life forms, ecological demand, and harmfulness of weed-flora species in energy-plant stands established in the studied area of Central Europe. The aim of this research was to confirm a possible influence of the taxonomical identity of cultivated energy crops on the weed composition of herbaceous layers in energy-plant plantations at the same type of management.

\section{Materials and Methods}

\subsection{Study Site and Experiment Design}

Experiments were established on agricultural land at the research center belonging to the Slovak University of Agriculture in Nitra, in the cadastral area of Kolínany (Nitra district area, SW Slovakia) at $180 \mathrm{~m}$ a.s.l. This region's climate is warm and very dry, with an average annual temperature 
of $9.6^{\circ} \mathrm{C}$ (average temperature ranges from 15 to $17^{\circ} \mathrm{C}$ during the growing season from March to October), and average rainfall of $560 \mathrm{~mm}$. Soil at the research site features fluvial soils and Haplic

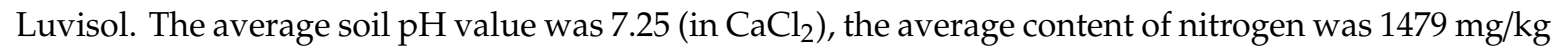
(according to Kjeldahl), and the average percentage of humus content was $2.31 \%$ (based on $\mathrm{C}_{\mathrm{ox}}$ ). The terrain-steepness aspect was a plain without a sign of surface erosion $\left(0^{\circ}\right.$ to $\left.1^{\circ}\right)$.

The plantations were established in the spring of 2009, with an effective mechanical and chemical weed control eradicating all weeds in the first year. During the first winter after establishing the plantation, the stems were cut back to ground level to support the growth of multiple stems. From 2010, no agricultural practices have been provided except of harvesting the woody biomass in the fifth and eighth year after planting (willow, poplar) and the herb biomass every year (miscanthus). The research area consisted of three blocks, each block was divided in three or five fields: one block for five different willow varieties (the selected target varieties for our research analysis were Tordis and Inger), one for five poplar varieties (the selected variety was Pegaso) and one for three miscanthus clones (the selected clone was Miscanthus $\times$ giganteus). Each field with one variety or clone within a block had a total area of $75 \mathrm{~m}^{2}$ and compact blocks were separated by $5 \mathrm{~m}$ wide ploughed corridors between each other. Each energy-plant species or variety had a stand with an extent of $75 \mathrm{~m}^{2}$. The area of the permanent sampling plots ( 1 sampling plot $=1$ quadrant) was $25 \mathrm{~m}^{2}(2.5 \times 10 \mathrm{~m})$ per species or variety and was situated in the middle of the studied field to exclude the edge effect.

\subsection{Description of Species and Varieties}

Tordis (Salix schwerinii $\times$ Salix viminalis) $\times$ Salix viminalis is a hybrid between Swedish varieties Tora and ULV, and Inger (Salix triandra $\times$ Salix viminalis) is a cross between a Russian clone and Swedish variety Jorr. The Salix plantations were established by planting cuttings in double rows with a distance of $1 \mathrm{~m}$ between rows in the double row. The distance between two double rows was $2 \mathrm{~m}$.

Poplar variety Pegaso is a hybrid of Populus $\times$ generosa $\times$ Populus nigra, planted in double rows spaced $1 \times 0.75 \mathrm{~m}$, and the distance between the double rows was $2 \mathrm{~m}$.

Miscanthus $\times$ giganteus is a sterile hybrid that cannot form fertile seeds as a consequence of its triploidy [21,22]. The miscanthus plantation was established by planting the rhizomes with a spacing of $1 \times 1 \mathrm{~m}$.

\subsection{Sampling and Data Analysis}

The method used for recording the weed composition was sampling by phytocoenological relevés from the whole permanent sampling plots of $25 \mathrm{~m}^{2}$. In the sampling survey, the presence of species and their relative abundance were assessed using a modified scale of covers and abundance according to Braun-Blanquet $[23,24]$. The survey was performed during nine consecutive growing seasons between 2010 and 2018 at 14-day intervals (from March to April, 16 times a year). The species nomenclature was updated according to The Plant List [25] created by the Royal Botanic Gardens (Kew) and the Missouri Botanical Garden.

When assessing the proportion of weed species, we considered a weed to be a plant, the population of which grows entirely or predominantly in situations markedly disturbed by humans (without being deliberately cultivated [17]). Weed species were included in systems valid for the environmental conditions of Slovakia according to Líška et al. [26].

The Jaccard index (Jaccard similarity coefficient) was used to assess differences in species composition of weeds on the four research plots. The index measures the similarity between finite sample sets, and is defined as the size of the intersection divided by the size of the union of the sample sets as follows:

$$
\mathrm{J}(\mathrm{A}, \mathrm{B})=\frac{|\mathrm{A} \cap \mathrm{B}|}{|\mathrm{A}|+|\mathrm{B}|-|\mathrm{A} \cap \mathrm{B}|}
$$

where J(A, B), the Jaccard index; A, the number of plant species in a research plot; and B, the number of plant species in the compared plot. 
Species habitat preferences were based on categories described by Ellenberg et al. [27], and Dölle and Schmidt [28]: arable field (a), grassland (g), ruderal site (r), and woodland (w) species. Some species were assigned to more than one group of habitat preferences $(\mathrm{a} / \mathrm{r} ; \mathrm{g} / \mathrm{r}$, respectively).

According to life cycle, annual plants (one-year life cycle), biennials (two-year life cycle), and perennials (three-or-more-year life cycle) were distinguished. Tree and shrub species were grouped separately for their realized or potential ecological traits and functions. The life forms were classified according to Raunkiaer [29] and sensu Ellenberg et al. [27]: T, therophytes; G, geophytes; $\mathrm{H}$, hemicryptophytes; $\mathrm{C}$, herbaceous chamaephytes; $\mathrm{z}$, ligneous chamaephytes; $\mathrm{N}$, nanophanerophytes; and $\mathrm{P}$, ligneous phanerophytes. We considered this classification for the potential life cycle of weeds contrary to the fact that all studied spontaneous plants in our research were manifested exclusively in the herbaceous layer reaching the lower layer of shrubs (usually up to $0.3-0.6 \mathrm{~m}$, rarely up to $1 \mathrm{~m}$ ). As a consequence of short cycle harvests, the trees and shrubs only grew as juvenile plants comparable to herbs by their size and ecological functions. In our case, juvenile ligneous phanerophytes and ligneous chamaephytes ("woody plants") were classified as part of the herbaceous layer.

Ecological demands of species were based on values of Ellenberg, including requirements for light, temperature, continentality, moisture, soil reaction, and nitrogen [27]. Ecological analysis of the weed composition in each sample plot was done using multivariate-ordination methods in Canoco software for Windows, version 4.5 (Microcomputer Power, Ithaca, NY, USA, sensu ter Braak [30], ter Braak and Šmilauer [31]). The method used for this analysis was chosen for linear and statistically indirect interactions (principal component analysis, PCA) between the average Ellenberg indicator for each factor in each variant.

From the viewpoint of harmfulness, weeds were classified into three groups [26]. Plants that have massive growth are deep-rooted, and pose serious danger to crops even at low numbers are usually considered "very dangerous weeds". It is necessary to pay increased attention to these weeds and to apply radical (mechanical or chemical) or combined (mechanical-chemical) measures. Species with high reproductive coefficients must be regulated even at low occurrences. "Less dangerous weeds" (occasional and transient) are of medium size and do not present a potential danger to the crops in the integrated stands under a normal weed-infestation rate. "Less significant (negligible) weeds" or "nondangerous weeds" are species with a smaller (shorter) growth, which are located in the ground layer of the stand and are less overgrown. Under normal occurrences, these weeds do not pose a serious danger to crops. Special regulatory interventions (the application of targeted radical chemical and/or mechanical measures) are unnecessary; it is sufficient to use common agrotechnical operations, and to maintain an integrated and complete crop stand in good condition and health.

\section{Results}

\subsection{Species Composition and Habitat Preferences}

In the stands of Salix, Populus, and Miscanthus $\times$ giganteus, 98 vascular plant species were found. These comprised 82 herbaceous species and 16 woody species (11 in Tordis, 6 in Inger, 5 in Pegaso, and 5 in miscanthus). The highest number of species was recorded for willow varieties Tordis and Inger (58 identically), and the lowest was recorded for poplar variety Pegaso (45). There were $16.33 \%$ woodland species, $10.20 \%$ arable-land species, and $16.33 \%$ grassland species found in the understory of the studied plots, with the highest percentage of ruderal species $(28.57 \%)$. The rest can be classified as common species of arable lands and ruderal sites or that of grasslands and ruderal sites. The habitat preferences of different weed species in the studied plots are given in Table 1.

The weed floras had different similarities in species composition (Table 2). The largest similarity was observed between willow variety Inger and Miscanthus $\times$ giganteus, and the lowest was between willow variety Tordis and poplar variety Pegaso, and poplar variety Pegaso and Miscanthus $\times$ giganteus. These big differences can be caused by the different utilization and allocation of sources and dissimilar growth and harvest frequency of trees and tall grasses. The following species occurred in the understory 
of all four sampling plots: Chenopodium album, Cirsium arvense, Convolvulus arvensis, Elymus repens, Epilobium hirsutum, Equisetum arvense, Lactuca serriola, Lathyrus tuberosus, Lepidium draba, Prunus padus, Stenactis annua, Symphyotrichum novi-belgii, Symphytum officinale, Taraxacum officinale, Torilis japonica, Tripleurospermum inodorum, Veronica persica, and Viola arvensis.

Table 1. Species representation based on species habitat preferences [\%].

\begin{tabular}{ccccc}
\hline Species Habitat Preferences & $\begin{array}{c}\text { Willow } \\
\text { Tordis }\end{array}$ & $\begin{array}{c}\text { Willow } \\
\text { Inger }\end{array}$ & $\begin{array}{c}\text { Poplar } \\
\text { Pegaso }\end{array}$ & Miscanthus $\times$ giganteus \\
\hline Woodland & 18.97 & 10.34 & 13.33 & 7.55 \\
Arable land & 10.34 & 12.07 & 11.11 & 15.09 \\
Grassland & 25.86 & 31.03 & 35.56 & 28.30 \\
Ruderal sites & 12.07 & 12.07 & 13.33 & 13.21 \\
Arable land and ruderal sites & 17.24 & 17.24 & 11.11 & 20.75 \\
Grassland and ruderal sites & 5.17 & 6.90 & 4.44 & 7.55 \\
Not stated & 10.34 & 10.34 & 11.11 & 7.55 \\
\hline
\end{tabular}

Table 2. Number of weed species in different energy crops (second column), number of shared species between two samples (bold), and similarity of weed-species composition in different energy crops evaluated by Jaccard index (italics).

\begin{tabular}{lccccc}
\hline & Number of Weed Species & $\begin{array}{c}\text { Willow } \\
\text { Tordis }\end{array}$ & $\begin{array}{c}\text { Willow } \\
\text { Inger }\end{array}$ & $\begin{array}{c}\text { Poplar } \\
\text { Pegaso }\end{array}$ & Miscanthus $\times$ giganteus \\
\hline $\begin{array}{l}\text { Willow variety } \\
\text { Tordis }\end{array}$ & 58 & - & 0.526 & 0.288 & 0.542 \\
\hline $\begin{array}{l}\text { Willow variety } \\
\text { Inger }\end{array}$ & 58 & $\mathbf{4 0}$ & - & 0.556 & 0.586 \\
\hline $\begin{array}{l}\text { Poplar variety } \\
\text { Pegaso }\end{array}$ & 45 & $\mathbf{2 3}$ & $\mathbf{2 5}$ & - & 0.289 \\
\hline Miscanthus $\times$ giganteus & 53 & $\mathbf{3 9}$ & $\mathbf{4 1}$ & $\mathbf{2 2}$ & - \\
\hline
\end{tabular}

\subsection{Life Cycle}

Perennial species (45.92\%) were dominant among all vascular plant species. The proportion of annual species was $28.57 \%$, that of biennial species was $9.18 \%$, and that of trees and shrubs was $16.33 \%$. The highest proportion of perennial species was found for Pegaso (55.55\%), and the lowest was found for Tordis, with $43.4 \%$. The highest share of trees and shrubs was recorded for Tordis, with $22.41 \%$.

\subsection{Life Forms}

The highest proportion $(27.66 \%)$ was represented by therophytes and hemicryptophytes. Comparable occurrence was found for species that change their life forms, namely, geophyte-hemicryptophyte species $(11.70 \%)$ and hemicryptophyte-therophyte species (10.64\%). Ligneous chamaephytes and stunted shrubs (growing to a height of $0.5 \mathrm{~m}$ ) represented a negligible proportion, with $1.06 \%$ (Figure 1). 


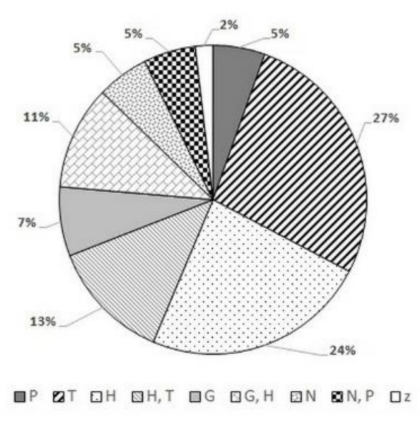

(a)

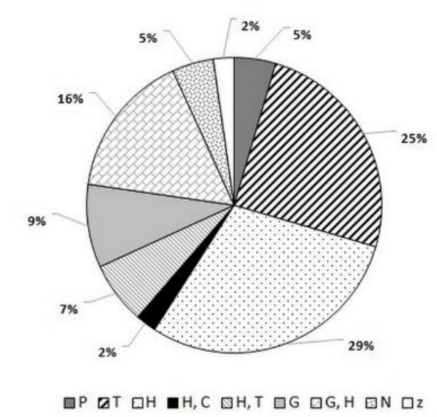

(c)

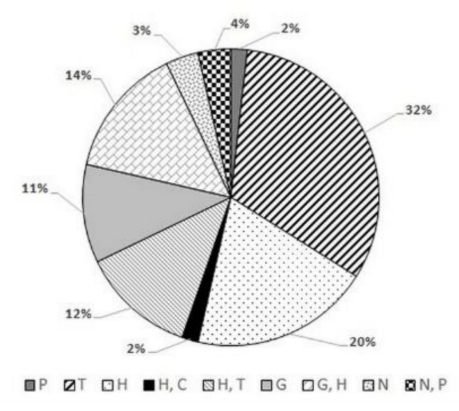

(b)

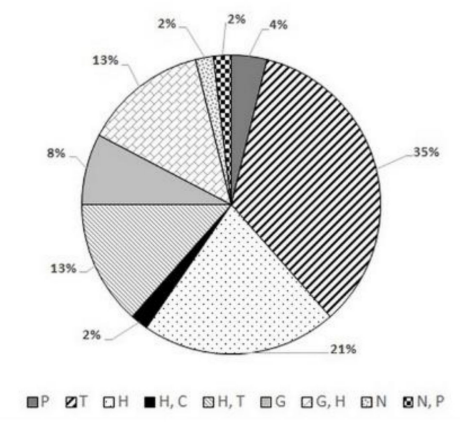

(d)

Figure 1. Ground-layer vegetation groups by life form for (a) Tordis, (b) Inger, (c) Pegaso, (d) and Miscanthus. P, phanerophytes; T, therophytes; $\mathrm{H}$, hemicryptophytes; $\mathrm{H} / \mathrm{C}$, transient group hemicryptophytes and cryptophytes; $\mathrm{H} / \mathrm{T}$, transient group hemicryptophytes and therophytes; G, geophytes; G/H, transient group geophytes and hemicryptophytes; N, nanophanerophytes; N/P, transient group nanophanerophytes and phanerophytes; $z$, chamaephytes.

\subsection{Ground-Flora Evaluation According to Ecological Demands of Species}

The occurrence, growth, and life cycle of weeds in stands of different energy-tree and -grass varieties were partially influenced by different kinds of changed environmental features (changes in light intensity near the ground during the growing season, water balance, material flows, etc.), which generated changes in the make-up and phenotypic plasticity of organs, the phenology of species, and the vitality and development of generative organs.

- Light requirements. Species ranged from shade-tolerating and semi-shade-tolerating to light-demanding. The highest light-requirement category included five species: Arctium lappa, Dipsacus fullonum, Lactuca serriola, Lycium barbarum, and Symphyotrichum novi-belgii. Shade-tolerating to semi-shade-tolerating species were tree species Acer pseudoplatanus, Fraxinus excelsior and Prunus avium, and herb species Geum urbanum. The average values of Ellenberg's indicator numbers for weeds in different energy crops ranged from 6.81 to 6.98 , suggesting that most species had higher light requirements, often growing in full light, but they tolerated the shade in energy plantations well.

- Temperature requirements. Only one species, Juglans regia, belongs to a species with high-temperature requirements, and one species, Senecio nemorensis, is a species with low-temperature requirements. The average value of the indicator numbers for each variant ranged from 5.76 to 5.93 , and most species extended from the hills to the lower mountain locations (mild-to-warm climate).

- Continentality. The average continentality-indicator values for each variant ranged between 4.08 and 4.21, indicating that most species are typical for the suboceanic climate of Central Europe (with continental to subcontinental species Calamagrostis epigejos, Chenopodium ficifolium, 
Elymus repens, Lactuca serriola, Lepidium draba, Plantago media, and Senecio nemorensis; and maritimity species Heracleum sphondylium, Juglans regia, and Symphyotrichum novi-belgii,).

- Moisture requirements. The average indicator values for different energy-plant stands varied from 5.03 to 5.07, which indicated that most occurring species require moist soils (lacking in wet and in frequently dry soils). One species required wet soils (Silene baccifera), and three species were drought-tolerant (Euphorbia cyparissias, Lepidium draba, and Veronica spicata).

- Soil-reaction requirements. The average indicator values for each variant ranged from 6.79 to 7.1, which indicated species that mostly prefer alkalic soils (pH 6.5-8). Mentha longifolia was one species demanding soils very rich in calcium, and Viola canina is a species that requires acidic soils.

- Nitrogen requirements. We identified three species that occur in soils with high nitrogen concentrations (Calystegia sepium, Sambucus nigra, and Symphyotrichum novi-belgii), and three species of soils that occur in areas poor in nitrogen (Hypericum maculatum, Veronica spicata, and Viola canina). The average indicator values for each energy-plant stand was in the range of 6.39-6.7, so most species were typical species occurring in medium-to-rich nitrogen soils.

The principal components analysis (PCA) of relationships between the Ellenberg indicator values of ground-flora species in different plots (Figure 2) showed that all factors had approximately the same driving strength (importance) for our computation within the studied plots (cf. the same length of axes). Furthermore, the closest statistical relationship in terms of species composition was between light intensity and continentality, and between temperature requirements and soil mineral nitrogen content. The moisture was correlated with temperature and mineral nitrogen negatively and its relation to other analyzed factors was almost neutral (slightly positive to $\mathrm{pH}$ and slightly negative to light intensity and continentality). The ground flora of the Tordis variety was relatively poorly influenced by its specific environmental conditions. The herbaceous layer of the Inger variety was mainly defined by soil reaction. The vascular plants in the undergrowth of both Miscanthus $\times$ giganteus and poplar trees (Pegaso) had the greatest affinity to mineral nitrogen content and temperature requirements.

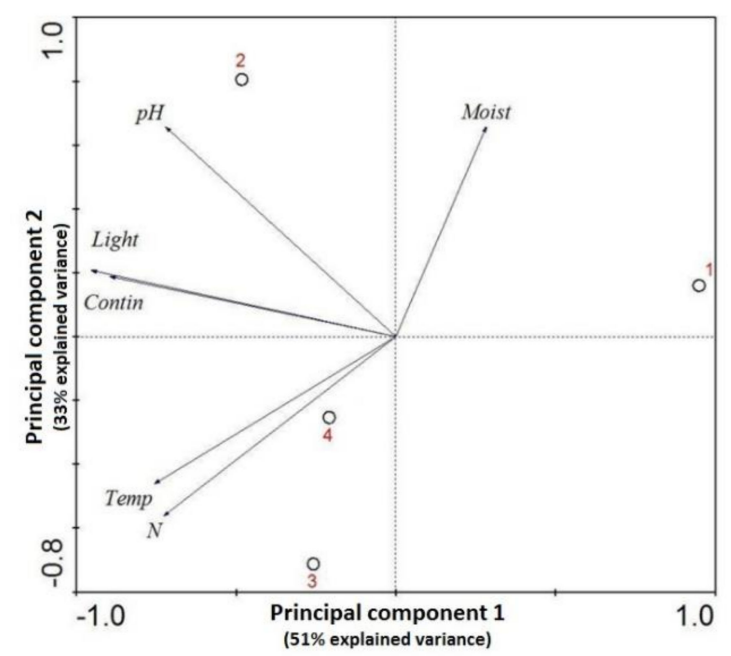

Figure 2. Principal components analysis (PCA) of relationships between Ellenberg indicator values of ground-flora species in different plots: (1), Tordis (willow); (2), Inger (willow); (3), Pegaso (poplar); and (4), Miscanthus $\times$ giganteus. Ellenberg indicator values: Moist, moisture; $\mathrm{pH}$, soil reaction; Light; Contin, continentality; Temp, temperature; and N, nitrogen.

\subsection{Weed-Species Harmfulness}

Fifty percent of all spontaneous plant species in the studied energy plantations are considered weeds in Slovakia. The "very dangerous" category represented $46.94 \%$ of weeds, the "less dangerous" category represented $51.02 \%$, and the "nondangerous" category represented $2.04 \%$ of the 49 species. 
"Very dangerous species", such as Chenopodium album, Cirsium arvense, Convolvulus arvensis, Elymus repens, Equisetum arvense, Lepidium draba, Taraxacum officinale, and Tripleurospermum inodorum, were found in all studied plots. The highest share of "very dangerous weeds" was found on plots with poplar Pegaso (38.78\% of all weeds in the variant), it was less in willow stands (32.65\% in Inger and $28.57 \%$ in Tordis), and the smallest proportion was recorded in miscanthus (26.53\%). The most abundant "very dangerous" weed species were Cirsium arvense, Convolvulus arvensis, Equisetum arvense, Galium aparine, Lepidium draba, and Taraxacum officinale. Moreover, $61.20 \%$ of arable-land species belonged to this category.

\section{Discussion}

Several authors point to the fact that SRC and perennial energy-grass stands (willow, poplar, and miscanthus) can positively affect local biodiversity $[3,9,32,33]$. On the other hand, our results showed that half of vascular plants in understory could be classified as weeds, and weeds can be harmful (see also [4]). In our research, the total number of vascular plant species was 98. Comparable results were reported by Baum et al. [34], who listed 79 and 98 species in Swedish and German research plots, respectively. In Poland, 63 and 68 spontaneous vascular plant species were found [4]. We observed 53 species in the miscanthus stand. Clapham and Slater [10] recorded 31 weed species within the miscanthus plantation, with Epilobium montanum, Ranunculus repens, and Rumex obtusifolius being the most frequently observed. Several studies [35-37], point to the fact that SRC species, as well as their varieties, influence the understory composition. We assume that this influence is due to different environmental conditions created by SRC crops. In some cases, seasonal meteorological conditions were more important than the taxonomic or genetic identity of energy crops [38].

The comparison of plant-species habitat preferences showed the largest proportion of ruderal species in the SRC plots, which does not correspond with the findings of Baum et al. [34], who recorded the largest proportion among grassland species. Weed floras in the tree and herb energy crops of Poland included $78 \%$ and $79 \%$ segetal and ruderal species, $16 \%$ and $18 \%$ meadow species, and $3 \%$ and $6 \%$ forest species (averages from two different time scales) [4]. The overall percentage of woodland species was comparable to the findings of Verheyen et al. [39], with approximately $16 \%$. The percentage of segetal species in the SRC stands indicated their penetration from the surrounding agricultural land.

The most dominant species in the understory were perennial species, comprising $45.92 \%$ of all vascular plants in the plantations. Baum et al. [3] found similar perennial species to be the most common species in SRC research sites in Sweden and Germany (e.g., Cirsium arvense, Elymus repens, Taraxacum officinale, and Urtica dioica), but perennial-species composition in the study sites of willow SRCs in central Latvia was more different [14]. In Poland, the share of perennials in the tree and herb energy crops was $37 \%$ and $40 \%$ (averages from two different time scales) [4].

Regarding life forms, therophytes and hemicryptophytes presented the highest proportion, comprising $27.66 \%$ of the observed communities. This does not correspond with the results of Welc et al. [40], who recorded an average of $63 \%$ hemicryptophytes and $8 \%$ therophytes during the five growing seasons. The abundant occurrence of hemicryptophytes in energy crops indicates the missing soil disturbance (according to Welc et al.) [40], and the presence of therophytes can be explained by continuous expansions from the adjacent arable lands (energy plantations in our research were of smaller size and consequently more susceptible to airborne and other weeds). Lososová et al. confirmed that crop stands whose management involves less disturbances, such as cereals, harbored less geophytes and had higher species richness [41]. Plant species in energy stands have adapted to a wide range of environmental conditions. In some cases, light-demanding weeds prevailed [14,37]. A study by Archaux et al. [36] showed that soil moisture and soil nitrogen were major determinants of plant communities. Other authors report on the high share of weeds typical for fresh moisture soils in SRC [14,39]. In our research, the Ellenberg indicator values for mineral nitrogen content in the soil, most ground-flora species in the majority of plots were typical species requiring medium-to-rich nitrogen soils, as per the results of Verheyen et al. [39]. 
We identified $50 \%$ of weed species, $46.94 \%$ of which were harmful to agriculture. These results significantly differ from those of Verheyen et al. [39], who found few harmful weeds in SRC plots. The localities of endangered, rare, or protected plant species are priority habitats for conservation, and a short-rotation coppice can harbor such species (c.f. Fry and Slater [42]). In some cases, few rare species were found in SRCs [7], but their occurrence was not recorded during our study.

\section{Conclusions}

The ground flora of energy plantations is composed predominantly of synanthropic plants with a weedy character with the potential to colonize new areas. There are differences in the spontaneous phytodiversity between different species and varieties of energy plants, but the basic character of spontaneous vegetation remains stable. Similarities of weed floras between different sampling plots varied in a wide range (from 0.288 to 0.586 according to the Jaccard index). Despite several years of research, it is relatively difficult to evaluate the ground flora of SRC and energy-grass plantations, as species composition and its dynamics are influenced by different local and seasonal factors that have not been studied.

After our nine-growing-season-lasting research, we can confidently state the following:

- the total number of vascular plant species in SRC and miscanthus-stand understories (all plots) was 98. The highest number of species was recorded for the research plots with Tordis and Inger willow, and the lowest for the Pegaso poplar. Perennial species dominated, 10 of which were found in all plots. Ruderal therophytes and hemicryptophytes prevailed;

- weeds represented 49 species among all identified vascular plant species in the SRC and miscanthus understory, $46.94 \%$ of which were very harmful. Poplar plantation hosted the highest number of "very dangerous weeds", the least of them was observed in miscanthus stands (willow stands were intermediate). Non-native invasive species were also recorded in the ground flora;

- $\quad$ according to ecological requirements of weeds, most species have higher light requirements. For temperature requirements, the presented species are predominantly mild-to-warm suboceanic species. Species that prefer freshly moist alkalic soils that are medium-to-rich in mineral nitrogen predominated;

- weeds of the Tordis willow variety were the least influenced by the environmental conditions of the taxon of the energy plant. Weeds of the Inger willow variety were mainly defined by the soil reaction. Weeds in the undergrowth of miscanthus (Miscanthus $\times$ giganteus) and poplar trees (Pegaso) had the greatest affinity to soil nitrogen content and temperature requirements.

This research was conducted on experimental SRC and energy-grass plantations in southern Slovakia under specific natural conditions. Therefore, the results achieved in our research cannot be generalized for other areas/regions. Nevertheless, these results can broaden the inconsistent and mosaical knowledge on this new source of weeds on farmlands. The long-term and seasonal fluctuations have not been analyzed, as their field study needs a longer time span. In spite of these limitations, the analysis of which is a future task, our research confirmed the importance of the taxonomical identity of cultivated energy plant for weed composition in energy plantations in the same environmental conditions. It underlines the importance of the identification of the most harmful weeds for each energy plant species or variety for the regional climate and soil conditions.

Author Contributions: Conceptualization, E.P., P.P., L.K., and A.F.; methodology, L.K. and A.F.; software, L.K. and A.F.; validation, E.P. and L.K.; formal analysis, L.K. and E.P.; investigation, A.F., P.P., and L.K.; resources, A.F., P.P., and L.K.; data curation, A.F. and L.K.; writing-Original-draft preparation, E.P. and A.F.; writing-Review and editing, E.P., L.K., A.F., and P.P.; visualization, L.K. and P.P.; supervision, P.P.; project administration, L.K.; funding acquisition, L.K. All authors have read and agreed to the published version of the manuscript.

Funding: This research was funded by the Grant Agency of the Faculty of European Studies and Regional Development, Slovak University of Agriculture in Nitra, Slovakia, grant number 08/2017.

Conflicts of Interest: The authors declare no conflict of interest. 


\section{References}

1. Fehér, A.; Končeková, L.; Glemnitz, M.; Berger, G.; Pfeffer, H.; Herzon, I. Maintaining and promoting biodiversity. In Sustainable Agriculture; Jakobson, C., Ed.; Baltic University Press: Uppsala, Sweden, 2012; pp. 371-387. ISBN 978-91-86189-10-5.

2. Benton, T.G.; Vickery, J.A.; Wilson, J.D. Farmland biodiversity: Is habitat heterogeneity the key? Trends Ecol. Evol. 2003, 18, 182-188. [CrossRef]

3. Baum, S.; Bolte, A.; Weih, M. High value of short rotation coppice plantations for phytodiversity in rural landscapes. Glob. Chang. Biol. Bioenergy 2012, 7, 728-738. [CrossRef]

4. Feledyn-Szewczyk, B.; Matyka, M.; Staniak, M. Comparison of the effect of perennial energy crops and agricultural crops on weed flora diversity. Agronomy 2019, 9, 695. [CrossRef]

5. Vanbeveren, S.P.P.; Ceulemans, R. Biodiversity in short rotation coppice. Renew. Sustain. Energy Rev. 2019, 111, 34-43. [CrossRef]

6. Kuzovkina, Y.A.; Quigley, M.F. Willows beyond wetlands: Uses of Salix, L. species for environmental projects. Water Air Soil Pollut. 2005, 162, 183-204. [CrossRef]

7. Gustaffson, L. Plant conservation aspects of energy forestry-A new type of land use in Sweden. For. Ecol. Manag. 1987, 21, 141-161. [CrossRef]

8. Sage, R.B. Weed competition in willow coppice crops: The cause and extent of yield losses. Weed Res. 1999, 39, 399-411. [CrossRef]

9. Semere, T.; Slater, F.M. Ground flora, small mammal and bird species diversity in miscanthus (Miscanthus $\times$ giganteus) and reed canary-grass (Phalaris arundinacea) fields. Biomass Bioenergy 2007, 31, $20-29$. [CrossRef]

10. Clapham, S.J.; Slater, F.M. The biodiversity of established biomass grass crops. Asp. Appl. Biol. 2008, 90, 325-329.

11. Dauber, J.; Jones, M.B.; Stout, J.C. The impact of biomass crop cultivation on temperate biodiversity. Glob. Chang. Biol. Bioenergy 2010, 2, 289-309. [CrossRef]

12. Baum, S. Phytodiversity in Short Rotation Coppice Plantations. Ph.D. Dissertation, Fakultät für Forstwissenschaften und Waldökologie, Georg-August-Universität, Göttingen, Germany, 2012.

13. Langeveld, H.; Quist-Wessel, F.; Dimitriou, I.; Aronsson, P.; Baum, C.; Schulz, U.; Bolte, A.; Baum, S.; Kohn, J.; Weih, M.; et al. Assessing environmental impacts of short rotation coppice (SRC) expansion: Model definition and preliminary models. Bioenergy Res. 2012, 5, 621-635. [CrossRef]

14. Pučka, I.; Lazdina, D.; Bebre, I. Ground flora in plantations of three years old short rotation willow coppice. Agron. Res. 2016, 14, 1450-1466.

15. Volk, T.A.; Verwijst, T.; Tharakan, P.J.; Abrahamson, L.P.; White, E.H. Growing fuel: A sustainability assessment of willow biomass crops. Front. Ecol. Environ. 2004, 2, 411. [CrossRef]

16. Dornburg, V.; Faaij, A.; Verweij, P.; Langeveld, H.; van de Ven, G.; Wester, F.; van Keulen, H.; van Diepen, K.; Meeusen, M.; Banse, M.; et al. Climate Change Scientific Assessment and Policy Analysis: Biomass Assessment. Assessment of Global Biomass Potentials and Their Links to Food, Water, Biodiversity, Energy Demand and Economy-Main Report; Lysen, E., van Egmond, S., Eds.; Netherlands Environmental Assessment Agency MNP: Bilthoven, The Netherlands, 2008. Available online: http:/www.globalbioenergy.org/uploads/media/ 0801_WAB_-_Biomass_assessment.pdf (accessed on 12 September 2011).

17. Baker, H.G. The Evolution of Weeds. Annu. Rev. Ecol. Syst. 1974, 5, 1-24. [CrossRef]

18. Crawley, J.M. Biodiversity. In Plant Ecology; Crawley, J.M., Ed.; Blackwell Science: Oxford, UK, 1997; pp. 595-632. ISBN 0-632-03639-7.

19. Genovesi, P.; Shine, C. European Strategy on Invasive Alien Species; Council of Europe: Strasbourg, France, 2004. Available online: https://www.cbd.int/doc/external/cop-09/bern-01-en.pdf (accessed on 15 July 2019).

20. Hill, S.B.; Ramsay, J. Weeds as Indicators of Soil Conditions. EAP Publications no 67. Ecological Agriculture Projects, McGill University. 1997. Available online: http://www.eap.mcgill.ca/publications/EAP67.htm (accessed on 7 July 2018).

21. Greef, J.M.; Deuter, M. Syntaxonomy of Miscanthus $\times$ giganteus GREEF et DEU. Angew. Bot. 1993, 67, 87-90.

22. Lewandowski, I.; Clifton-Brown, J.C.; Scurlock, J.M.O.; Huisman, W. Miscanthus: European experience with a novel energy crop. Biomass Bioenergy 2000, 19, 209-227. [CrossRef] 
23. Braun-Blanquet, J. Pflanzensoziologie. Grundzüge der Vegetationskunde, 3rd ed.; Springer: New York, NY, USA, 1964; ISBN 978-3-7091-8111-9.

24. Mueller-Dombois, D.; Ellenberg, H. Aims and Methods of Vegetation Ecology; Wiley and Sons: New York, NY, USA, 1974; ISBN 0-471-62290-7.

25. The Plant List Version 1.1. Available online: http://www.theplantlist.org (accessed on 16 August 2020).

26. Líška, E.; Černuško, K.; Hunková, E.; Otepka, P. Biológia burín. (Biology of Weeds); VES SPU: Nitra, Slovakia, 2002; pp. 16-24. ISBN 80-8069-001-4. (In Slovak)

27. Ellenberg, H.; Weber, H.E.; Düll, R.; Wirth, V.; Werner, W.; Paulißen, D. Zeigerwerte von Pflanzen in Mitteleuropa. Scripta Geobotanica 18, 3rd ed.; Erich Goltze KG: Göttingen, Germany, 2001; pp. 1-262. ISBN 10-3884525182.

28. Dölle, M.; Schmidt, W. The relationship between soil seed bank, above-ground vegetation and disturbance intensity on old-field successional permanent plots. Appl. Veg. Sci. 2009, 12, 415-428. [CrossRef]

29. Raunkiaer, C. The life-forms of plants and their bearing on geography. In The Life Forms of Plants and Statistical Plant Geography; Raunkiaer, C., Ed.; Clarendon Press: Oxford, UK, 1934; pp. 2-104.

30. Ter Braak, C.J.F. Unimodal Models to Relate Species to Environment; DLO-Agricultural Mathematics Group: Wageningen, The Netherlands, 1996.

31. Ter Braak, C.J.F.; Šmilauer, P. CANOCO Reference Manual and CanoDraw for Windows User's Guide. Software for Canonical Community Ordination (Version 4.5); Microcomputer Power: Ithaca, NY, USA, 2002.

32. Delarze, R.; Ciardo, F. Rote Liste-Arten in Pappelplantagen (Red List Species in Poplar Plantations); Informationsblatt Forschungsbereich Wald, WSL: Birmensdorf, Switzerland, 2002; Volume 9, pp. 3-4. (In German)

33. Cunningham, M.D.; Bishop, J.D.; McKay, H.V.; Sage, R.B. ARBRE Monitoring-Ecology of Short Rotation Coppice; DTI: London, UK, 2004; p. 157.

34. Baum, S.; Weih, M.; Bolte, A. Floristic diversity in short rotation coppice (SRC): Comparison between soil seed bank and recent vegetation. Appl. Agric. For. Res. 2013, 63, 221-228. [CrossRef]

35. Britt, C.P.; Fowbert, J.; Mc Millan, S.D. The ground flora and invertebrate fauna of hybrid poplar plantations: Results of ecological monitoring in the PAMUCEAF project. Asp. Appl. Biol. 2007, 82, 83-90.

36. Archaux, F.; Chevalier, R.; Berthelot, A. Towards practices favourable to plant diversity in hybrid poplar plantations. For. Ecol. Manag. 2010, 259, 2410-2417. [CrossRef]

37. Birmele, J.; Kopp, G.; Brodbeck, F.; Konold, W.; Sauter, U.H. Successional changes of phytodiversity on a short rotation coppice plantation in Oberschwaben, Germany. Front. Plant Sci. 2015, 6, 1-8. [CrossRef] [PubMed]

38. Fehér, A.; Halmová, D.; Končeková, L. Gradient analysis of importance of spontaneously occurring vascular plant species in energy tree and grass stands. Acta Reg. Environ. 2013, 10, 33-35. [CrossRef]

39. Verheyen, K.; Buggenhout, M.; Vangansbeke, P.; De Dobbelaere, A.; Verdonckt, P.; Bonte, D. Potential of short rotation coppice plantations to reinforce functional biodiversity in agricultural landscapes. Biomass Bioenergy 2014, 67, 435-442. [CrossRef]

40. Welc, M.; Lundkvist, A.; Nordh, N.E.; Verwijst, T. Weed community trajectories in cereal and willow cultivations after termination of a willow short rotation coppice. Agron. Res. 2017, 15, 1795-1814. [CrossRef]

41. Lososová, Z.; Chytrý, M.; Cimalová, Š.; Kropáč, Z.; Otýpková, Z.; Pyšek, P.; Tichý, L. Weed vegetation of arable land in central Europe: Gradients of diversity and species composition. J. Veg. Sci. 2004, 15, 415-422. [CrossRef]

42. Fry, D.; Slater, F. The Biodiversity of Short Rotation Willow Coppice in the Welsh Landscape: A Report to the Institute of Biological, Environmental and Rural Sciences, Aberystwyth University for EU Project "Willows for Wales"; Aberystwyth University: Penglais, UK, 2009. Available online: https://www.aber.ac.uk/en/media/ departmental/ibers/research/willowforwales/Biodiversity-of-src-coppice-in-the-Welsh-Landscape.pdf (accessed on 14 February 2012).

(C) 2020 by the authors. Licensee MDPI, Basel, Switzerland. This article is an open access article distributed under the terms and conditions of the Creative Commons Attribution (CC BY) license (http://creativecommons.org/licenses/by/4.0/). 